INTERNATIONAL JOURNAL OF RESEARCHES IN BIOSCIENCES, AGRICULTURE \& TECHNOLOGY (C) VISHWASHANTI MULTIPURPOSE SOCIETY (Global Peace Multipurpose Society) R. No. MH-659/13(N) www.vmsindia.org

\title{
REGIONAL VARIATION OF TANNIN IN TRIPHALA DRUGS AND TRIPHALA CHURNA
}

\author{
Jadhav R. P. \\ Gopal Krishna Gokhale College, Kolhapur (M.S) India \\ Email: ravindrajadhav3535@gmail.com
}

\begin{abstract}
Triphaladrugs contain (Behda) TerminaliabelericaRoxb. (Harda) TerminaliachebulaRetz.and (Amala) PhyllanthusemblicaLinn. in equal proportion. It is unique herbal combination. The present paper deals with the physicochemical properties of Triphala drugs ingredients and Triphalachurna market sample. Physicochemical parameter like Water soluble extractive value, Alcohol soluble extractive value, Ash percentage and Tannin percentage of three drugs collected from four different region and market brand triphalachurna has been discussed Percentage of Tannin were highest in Terminaliabelerica followed by Terminaliachebula and lesser in Phyllanthusemblica.
\end{abstract}

Keywords: Terminalia, Triphala,Tannin, Extractive value, Physiochemical.

\section{Introduction:}

Triphala is a combination of the dried fruits of Terminaliachebula, Terminaliabelerica, and Emblicaofficinalis in equal proportions. These are popularly known in India as harad, behada and amla. Harada and behda have a warm energy, while amla is cool. Triphala, being a combination of all three and it is a unique, therefore balanced, making it useful as an internal cleansing, detoxifying formula for everyone including more sensitive type individuals and vegetarians.A popular folk saying in India says, "No mother? Do not worry so long as you have triphala."

The recipe for this traditional herbal supplement dates back thousands of years and is referenced in the traditional Indian texts the Charak and SushrutSamhitas. Triphala is considered a 'tridoshicrasayan', having balancing and rejuvenating effects on the three constitutional elements that govern human life. Vata which regulates the nervous system, Pitta which maintains metabolic processes, and Kapha which supports structural integrity. Triphala is one of the most popular herbal remedies which 'cleanse' by promoting bowel movement. A reason is that one of the most common problems among many individuals is constipation and bowel irregularity. This can lead to poorer general digestion and liver function, less vitality and perhaps even less optimism and an overall poorer outlook and quality of life.
Triphala combines both nutritional as well as blood and liver cleansing (detoxifying) actions. It has little function as a local demulcent but is more of a lubricating source of nourishment and also possesses some bitter anthroquinones which help stimulate bile flow and peristalsis. The nutritional aspect is partly in the form of its bioflavonoids, high vitamin-C content and the presence of linoleic oil, phospholipids and other important. Nutrients which it makes more of a tonic. Because of its high nutritional content, ayurvedic doctors generally do not regard triphala as a more laxative. Some of the scientific research and practical experience of people using it down through the ages has demonstrated that triphala is an effective blood purifier that stimulates bile secretion as it detoxifies the liver, helps digestion and assimilation, and significantly reduces serum cholesterol and lipid levels throughout body. As a result, it is regarded as a kind of universal panacea and is the most commonly prescribed herbal formula.

TerminaliabelericaRoxb.:

(Behda) belonging to family Combretaceae large deciduous tree found all over India. The fruit is bitter, astringent, tonic, attenuate, aperient, antipyretic; useful in dyspepsia, bilious headache, diarrhea, applied to eyes, to piles, brain tonic (Yunani). The part used in the medicine is the pulp. The seed is acrid, intoxicating; useful in thirst, vomiting, bronchitis, and corneal ulcers; relieves "vata" (Ayurveda). 
TerminaliachebulaRetz.: (Harda) belonging to family Combretaceae. A moderate sized or large deciduous tree. It has many common names but Harda is a famous commom name. The unripe fruits are astringent, and aperient, useful in dysentery and diarrhoea. The ripe fruit is purgative, tonic, carminative, enriches the blood, good in opthalmia, diseases of the spleen, piles, cold in the head, strengthens the brain, the eye, the gums, used in paralysis (Yunani). It contains $32 \%$ tannins, the plant of Teminalischebula is called the "the king of medicines" in the able of scavenging hydrogen. In allopathy, its extract is used as an astringent. It also consists of nutrients of vitamin C, protein, amino acids and minerals.

\section{PhyllanthusemblicaLinn.:}

(Amala) belonging to family Euphorbiaceae. A deciduous small or middle sized tree with crooked trunk and spreading branches. The fruit is acrid, sour, bitter, sweetish, cooling, carminative, alternative, laxative, tonic, antipyretic, useful in burning sensation, vomiting biliousness, urinary trouble, thirst, leprosy, inflammation, piles and anemia. The unripe fruit is cooling, diuretic and laxative. Mixtures of equal proportion of these three fruits are used in the preparation of "TriphalaChurna".

\section{Materials and method:}

Fresh mature fruits of the Terminaliabelerica, Terminaliachebula and Phyllanthusemblicawere collected from different regions of the Konkan and Thane. Fruits were collected from KeshavSrishti (Thane), Alibaug (Thane), Rajapur (Sindhudurg), Amboli (Sindhudurg), Savantwadi (Sindhudurg), Pernem (Goa), for analysis purpose. Fruits were dried, powdered and used for further work of analysis. Total Ash, Acid Insoluble Ash, Water Solubility, Alcohol Solubility and tannin percentage was carried out as per the methods suggested in Ayurvedic Pharmacopeia.(vol.-III, 1996), analysed by method suggested by Anopnymous (1984).

\section{Observation and discussion:}

The physicochemical properties of Harda, Baheda, Amla and TriphalaChurna are tabulated in Table 1. The percentage of total ash content was observed to be highest in TriphalaChurna (3.64) followed by Amla and least in Harda (0.93) found in Rajapur and had a range of $0.98-1.3 \%$ in Harda, 1.38 $1.68 \%$ in Behda and 2.81-3.64 \% in Amla. Acid Soluble Ash (ASA) was also was higher than acid insoluble ash in all sample. Percentage of solubility in water was higher in all samples than alcohol solubility. In behda tannin percentage was found maximum compare to other species. Sample collected from Rajapur of behda shows higher tannin content.

\section{Conclusion:}

Triphala is a novel drug with an array of therapeutic activities gifted by Ayurveda to the world. It has wide spectrum of pharmacological and medicinal activities, having a potential to treat a variety of human ills with minimal or no side-effects. This medicinal plant is the unique source of various types of compounds having diverse chemical structure. Percentage of solubility in water was higher show higher percentage of tannin. Total ash percentage show present of inorganic element in species.Total ash Percentage Values is inAmla higher as compared to others, and tannin Values are higher in Behda.
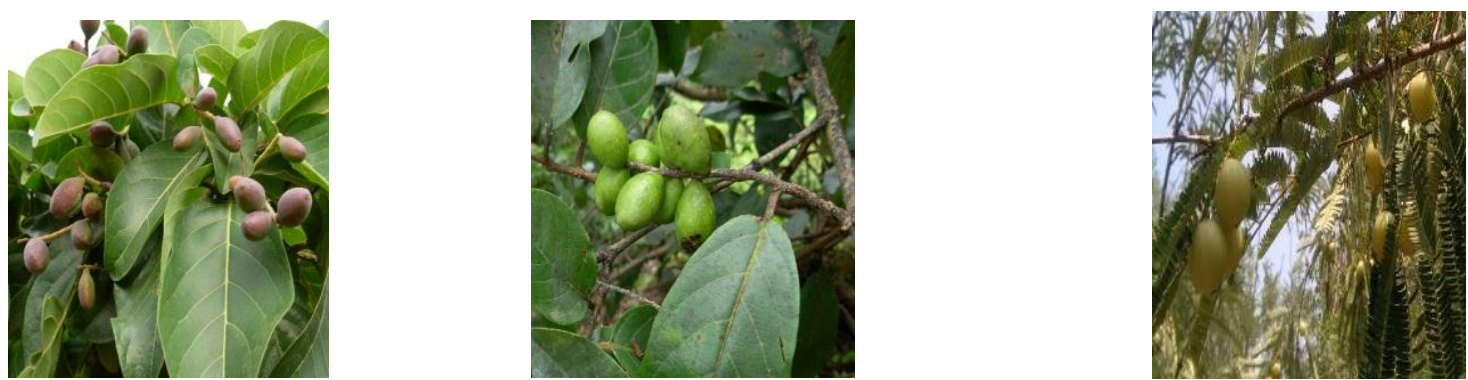

Figure 1. Fruits of Terminaliachebula, Terminaliabelerica and Phyllanthusemblica 
Table-1: Physicochemical parameters of Harda, Beheda, Amla and TriphalaChurna.

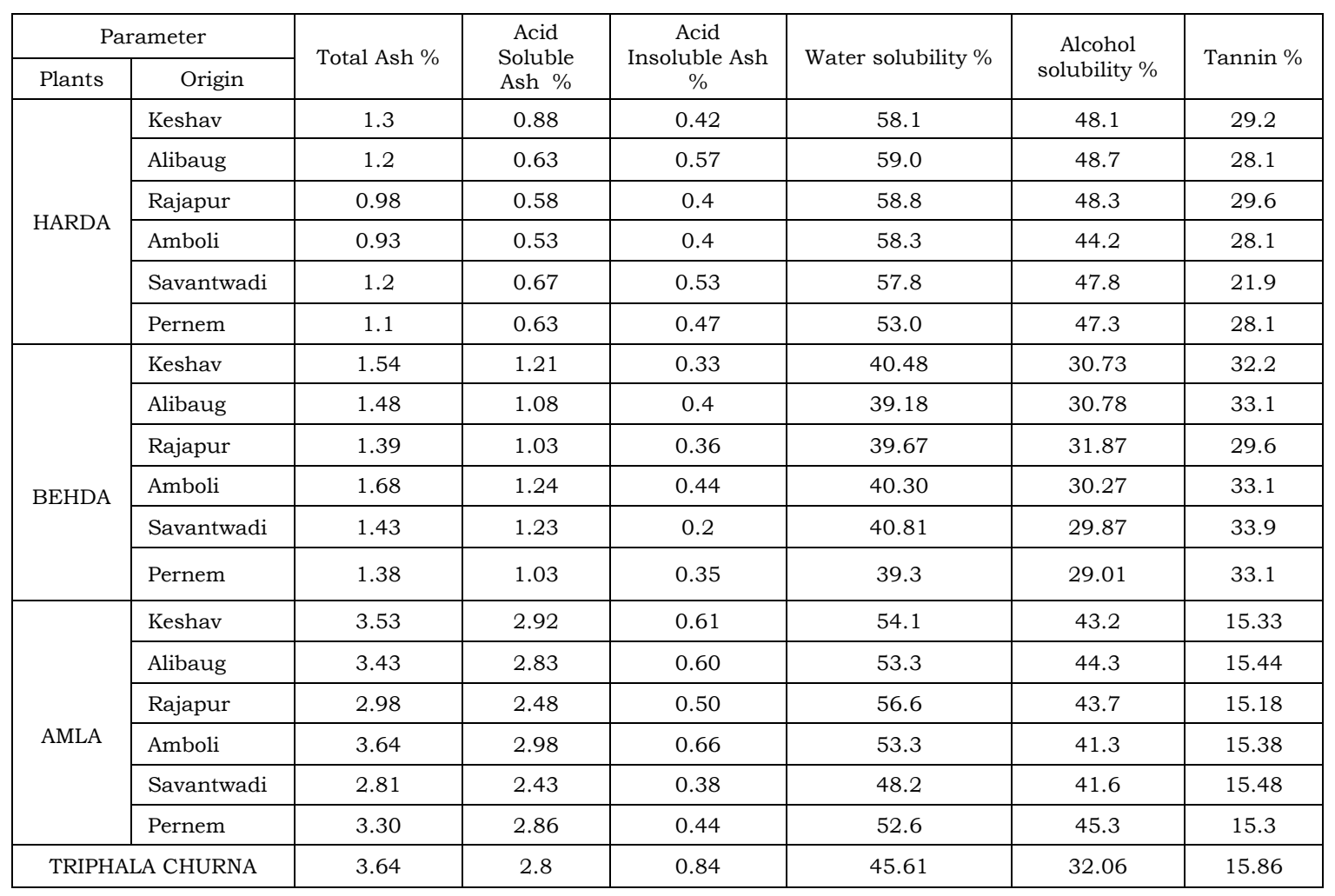

\section{Acknowledgement:}

Authors wish to expresstheirthanks to Dr. A.R. Kulkarni, Ex.HOD. Life Science, Mumbai and Dr. J. M.Pathak, Research Director, The Zandu Pharmaceutical Works Limited, Dr. R.M. Mulani, School of Life Science, SRTM Nanded, for valuable suggestions during the investigation and for going through the manuscript.

\section{References:}

Anonymous, (1976), Wealth of India: Raw material, Vol. X, CSIR New Delhi.

Anonymous, (1984), Association of official Agricultural Chemist(A.O.A.C.) Official Methods of Analysis (14thed.) The AssociationWashington D.C.

Anonymous, (1996),

Pharmacopoeia: The controller Publication: Delhi, Vol-II, 3rd Ed.

Chopra R.N., Nayar S.L., (1956), Glossary of Indian MedicinalPlants:CSIR, New Delhi, 426.

Chopra R.N., Chopra L.C., HandaK.D., KapurL.D., (1976), Indigenous Drugs of India: Ed.Third, 428.

Cook T., (1903), The flora of Presidency of Bombay, Vol.-I,SriGouranga Press Pvt. Ltd., Calcutta.
Gowda DV, Muguli G, Rangesh PR, Deshpande RD., (2012), Phytochemical and Pharmacologicalactions of triphala: Ayurvedic formulation, Int. J. Pharm Sci. Rev Res.61-65.

Johson, (1941), J.Bio. Chem., Cited from Whistler, 137, 575.

Juss S.S.,Triphala - The Wonder Drug. Indian Med. Gazette.(1997), 131(6), 194-96.

Kirtikar K.R., BasuB.D., Indian Medicinal Plants:Vol.-I Ed. second (1975), 77.

Mishra A.B., Bhavaprakash Nighantu, Vol.I (1969), 269.

NadkarniK.M., NadkarniA.K., (1976), Indian Material Medica, Vol.-I. Ed. 3rd, 1220.

Sharma P.V., DravyagunaVigynan, Vol.II,(1969), 680.

Vanit T. ET.AL., Antioxidant properties of the Ayurvedic formulation Triphala and its Constituents, International jour. Pharmacognosy, (1997), 35(5), 313-17.

Willigen D.E., Whistler R.L., Methodsin Carbohydrate Chemistry, Academic Press, Inc. New York, (1964) Vol.- IV 10. 